\title{
Physical activity of school children and youth
}

\author{
Leszek Tomaczkowski, Joanna Klonowska \\ Gdansk University of Physical Education and Sport in Gdansk, Poland
}

\section{abstract}

Physical activity is a key element of a healthy lifestyle, especially in relation to children and adolescents. It is crucial for proper physical, psychological and social development. Systematic physical activity tailored to individual needs stimulates development in childhood and adolescence and increases health resources.

An insufficient level of physical activity among children and adolescents, in comparison to the needs, is a problem occurring more and more commonly on a global scale. It has been confirmed in numerous research studies.

Key words: physical activity, health, children and adolescents.

\section{article details}

Article statistics: Word count: 1,245; Tables: 0; Figures: 3; References: 21

Received: December 2019; Accepted: April 2020; Published: June 2020

Full-text PDF: http://www.balticsportscience.com

Copyright @ Gdansk University of Physical Education and Sport, Poland

Indexation: Celdes, Clarivate Analytics Emerging Sources Citation Index (ESCI), CNKI Scholar (China National Knowledge Infrastructure), CNPIEC, De Gruyter - IBR (International Bibliography of Reviews of Scholarly Literature in the Humanities and Social Sciences), De Gruyter - IBZ (International Bibliography of Periodical Literature in the Humanities and Social Sciences), DOAJ, EBSCO - Central \& Eastern European Academic Source, EBSCO - SPORTDiscus, EBSCO Discovery Service, Google Scholar, Index Copernicus, J-Gate, Naviga (Softweco, Primo Central (ExLibris), ProQuest - Family Health, ProQuest - Health \& Medical Complete, ProQuest - Illustrata: Health Sciences, ProQuest - Nursing \& Allied Health Source, Summon (Serials Solutions/ProQuest, TDOne (TDNet), Ulrich's Periodicals Directory/ulrichsweb, WorldCat (OCLC)

Funding: This research received no specific grant from any funding agency in the public, commercial, or not-for-profit sectors.

Conflict of interests: Corresponding author:

Open Access License: Authors have declared that no competing interest exists.

Leszek Tomaczkowski, Gdansk University of Physical Education and Sport, Górski Str. 1, 80-336 Gdansk, Poland; e-mail: leszek.tomaczkowski@awf.gda.pl

This is an open access article distributed under the terms of the Creative Commons Attribution-Non-commercial 4.0 International (http://creativecommons.org/licenses/by-nc/4.0/), which permits use, distribution, and reproduction in any medium, provided the original work is properly cited, the use is non-commercial and is otherwise in compliance with the license. 


\section{INTRODUCTION}

Kasperczyk [1] states that movement is the most important factor after nutrition that affects our health. "In the improvement of the body's regulatory autosystems, it is undeniably the top priority". Physical activity models the morphological and functional state of the body the most favorably and it shapes mental features. According to the definition by Caspersen et al. [2, p. 126], "physical activity is any body movement triggered by muscles that causes energy expenditure". Physical activity suitably adapted to age and physical fitness is the best way to maintain health, well-being and longevity [3]. There are three important reasons for practicing systematic, rather intense and appropriately long-lasting physical activity by children and adolescents. Firstly, physical activity creates an opportunity for optimal physical and mental development and social. It is also fundamental to the development of the body's health resources. Secondly, through physical activity, we shape a healthy lifestyle for children and adolescents that they can bring into adult life. Thirdly, regular physical activity reduces the risk of diseases in both childhood and adult life [4].

\section{PHYSICAL ACTIVITY IN CHILDREN AND YOUTH}

The World Health Organization recommends that children and adolescents aged 5-17 participate in physical activity on a daily basis, for a total of at least 60 minutes during the day, at least moderate intensity activity, with a higher dose of physical activity providing additional health benefits. Most of the daily physical activity should be in the nature of aerobic effort. Additionally, high intensity exercises should be included, and 3 times a week - exercises strengthening the locomotor apparatus and affecting flexibility [5]. In addition, attention was paid to the time spent in front of the computer and TV, which on school days should not exceed two hours. The World Health Organization also calls for increased public and school involvement in providing sports facilities after lessons, at weekends, during summer and winter holidays, so that children and young people could freely use them. Low physical activity is one of the basic factors causing many metabolic diseases, among others: obesity, cardiovascular diseases, type 2 diabetes, many cancers, as well as osteoporosis [6]. It is especially important to instill an active lifestyle in childhood and early youth, when habits related to health-promoting behaviors are established.

Meanwhile, the rapid development of civilization negatively affects young people's physical activity. Insufficient level of physical activity is the cause of adverse changes in the body, including obesity [7]. It should be emphasized that almost $17 \%$ of Polish children and adolescents are overweight or obese [8]. Looking at the leisure time behavior of children aged 9-12, the severity of sedentary behavior is observed [9, 10]. According to Woynarowska and Mazur [11], school physical education is the only source of physical activity for about $60 \%$ of school-age children and adolescents. Studies on European youth have shown that boys are more physically active than girls [12]. Similar results were obtained by Tudor-Locke et al. [13], who showed that girls are less active in their free time and take fewer steps than their colleagues. Analogous differentiation has been confirmed by Groffik's studies [14]. A low level of physical activity is a basic public health problem in developed countries. Studies have shown that in the US more than half of the teen population participates in moderate physical activity less than three times a week [15], while the number of hours spent by teenagers in front of the screen is on average five hours a day. A sedentary lifestyle predominates in the behavior of young people in developed countries, especially in American youth, where this phenomenon was observed 
the earliest [16]. HBSC (Health Behavior in School-Aged Children) research has been carried out cyclically every four years since 1982. It relates to health and development, including pro-health behavior, risky behavior and the social context of health. Currently, 49 countries or regions from Europe and North America are members of the research network. Poland has been a member since 1989, which has allowed this research to be carried out eight times here.

Comparing the data from two rounds of HBSC research, i.e. from 2014 and 2018, the authors of the report concluded that the percentage of young people meeting the recommendations of the World Health Organization (WHO) in the field of moderate physical activity fell by 7 percentage points - from $24.2 \%$ to $17.2 \%$ [17]. As part of the Active Healthy Kids Global Alliance project, the latest summary of the state of knowledge about physical activity of children and adolescents in Poland has been published and in almost 50 other countries around the world [18]. The authors of the report pointed out that Poland performs averagely when it comes to the conditions of physical activity of children and youth. The school-related indicator in Poland looks positive compared to other indicators, which results from a relatively large number of physical education lessons, their obligatory nature, good attendance, a significant proportion of staff who are qualified to conduct physical education classes. However, the fact that the indicators characterizing the behavior itself are very bad is worrying. According to the authors of the WHO report on physical activity of adolescents, published at the end of November 2019 in "The Lancet Child \& Adolescent Health" [19], in all analyzed regions of the world, girls were found to be less physically active than boys. The authors of the report also note the significant difference $-7.1 \%$ in insufficient physical activity between the sexes. The authors did not observe significant dependencies in the results of surveys conducted in countries belonging to groups divided by national income. The region of the world where the problem of insufficient physical activity is the most common is rich countries in the Asia-Pacific region - Singapore and South Korea. The ratio for boys there is $89 \%$, for girls as much as $95.6 \%$.

Poland is no exception to the disproportion of girls' vs. boys' physical activity. In 2016 , the difference was $10.5 \%$ in favor of boys and widened by $1.4 \%$, compared to $2001.84 .2 \%$ of girls were insufficiently physically active in 2016 . This is almost the same result compared to 2001. An improvement was recorded with the indicator for boys. In 2001, $75.2 \%$ of boys did not undertake sufficient physical activity, in $2016-3.7 \%$.

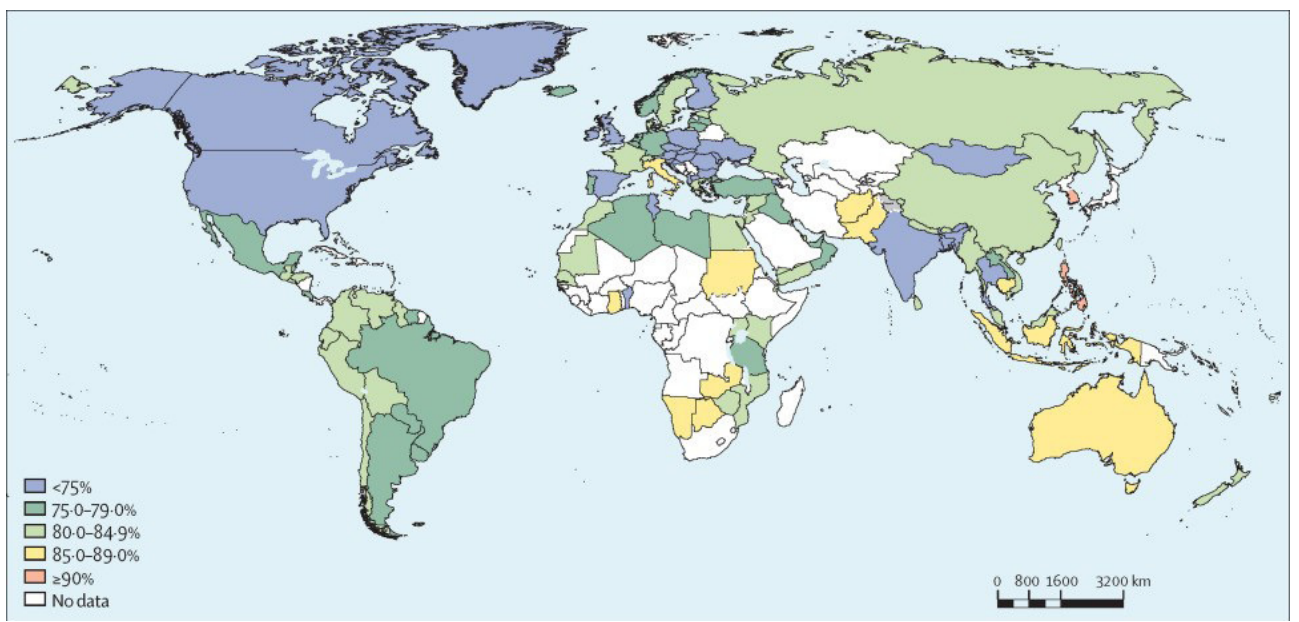

Fig. 1. Boys aged 11-17 attending school and not undertaking sufficient physical activity in 2016 [19] 


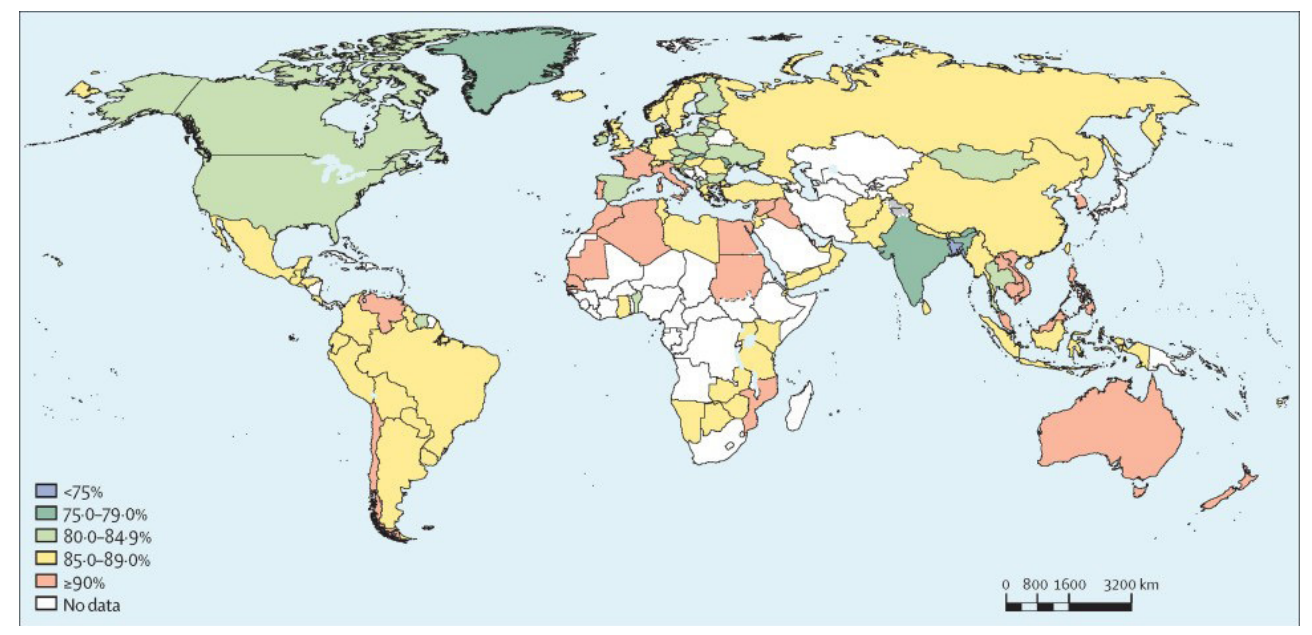

Fig. 2. Girls aged 11-17 attending school and not undertaking sufficient physical activity in 2016 [19]

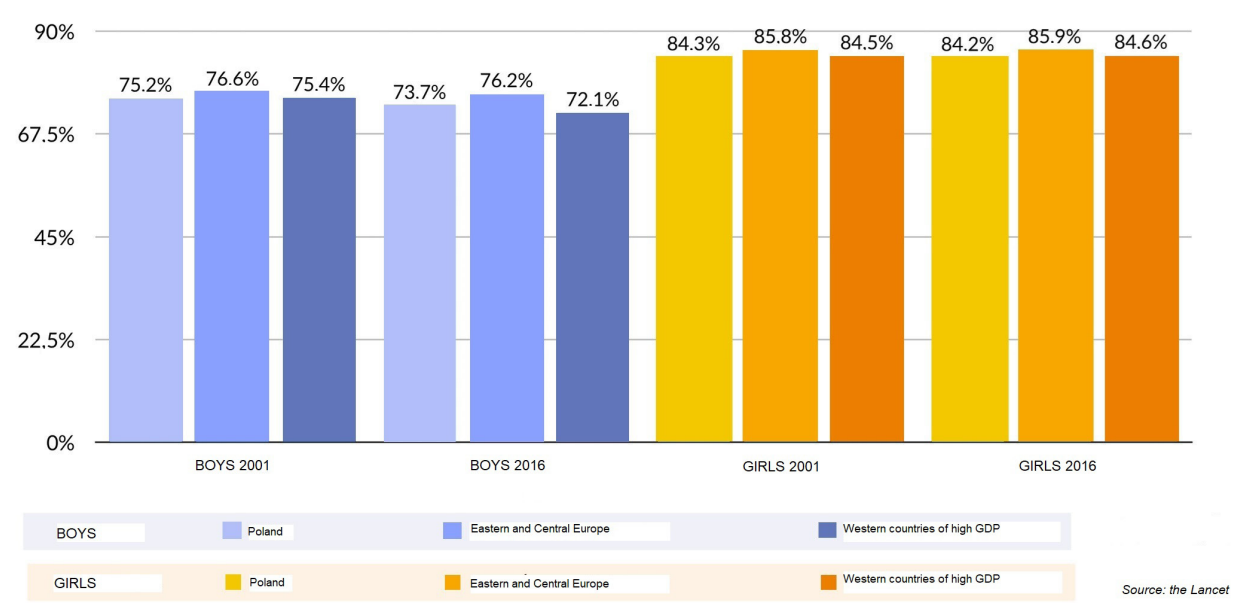

Fig. 3. School adolescents aged 11-17 attending school and not undertaking sufficient physical activity in 2016 [19]

In 2018, the World Health Organization [20] inaugurated More Active People for a Healthier World). Its goal is to reduce by $15 \%$ the indicators of insufficient physical activity of youth and adults up to the year 2030. The authors of the report emphasize that if the currently observed trends continue, the global goal of $15 \%$ reduction of insufficient physical activity will not be achieved by 2030. They also expressed a need to take immediate action to promote physical culture among young people. "Investments and leadership at all levels aimed at fixing many problems and inequalities, [...] as well as the involvement of young people themselves is necessary to strengthen the possibilities of physical activity" - they stated in the report [21].

\section{CONCLUSIONS}

Physical activity and sport should be promoted among young people, and they should be encouraged to exercise daily, by influencing the school and home environment of students. Implementation of programs promoting physical activity and a healthy lifestyle brings positive results in this respect. 


\section{REFERENCES}

[1] Kasperczyk T. Poziom sprawności i aktywności fizycznej a zdrowie [The level of fitness and physical activity and health]. Nowa Medycyna. 2000;108(12):88-90. Polish.

[2] Caspersen C, Powell K, Christenson G. Physical activity, exercise and physical fitness: definitions and distinctions for health-related research. Public Health Reports. 1985;100(2):126-131.

[3] Drabik J. Aktywność fizyczna w kształtowaniu zdrowia człowieka - korzyści i zagrożenia [Physical activity in shaping human health - benefits and threats]. Wychowanie Fizyczne i Sport. 1999;4:124125. Polish.

[4] Mazur J. Aktywność fizyczna młodzieży szkolnej w wieku 9-17 lat. Aktualne wskaźniki, tendencje ich zmian oraz wybrane zewnętrzne i wewnętrzne uwarunkowania. Projekt realizowany na zlecenie Ministerstwa Sportu i Turystyki cz. I - badania ilościowe [Physical activity of schoolchildren aged 9-17. Current indicators, trends of their changes and selected external and internal conditions. Project implemented on behalf of the Ministry of Sport and Tourism, part I - Quantitative research. Warszawa: Institute of Mother and Child; 2013. Polish.

[5] Global Recommendations On Physical Activity For Health. WHO: Geneva, 2010.

[6] Charzewska J, Wajszczyk B, Chabros E, et al. Aktywność fizyczna Polsce w różnych grupach według wieku i płci [Physical activity in Poland in various groups by age and sex]. In: Jarosz M, editor. Otyłość, żywienie, aktywność fizyczna, zdrowie Polaków [Obesity, nutrition, physical activity, health of Poles]. Warszawa: Food and Nutrition Insitute; 2006, 311-340. Polish.

[7] Mota J, Santos P, Guerra S, Ribeiro J, Duarte J. Difference of Daily Physical Activity Levels of Children According to Body Mass Index. Pediatr Exerc Sci. 2002;14:15-47. https://doi.org/10.1123/pes.14.4.442

[8] Grajda A, Kułaga Z, Gurzkowska B, Napieralska E, Litwin M. Regional differences in prevalence of overweight, obesity and underweight among Polish children and adolescents. Medycyna Wieku Rozwojowego. 2011;15:258-265.

[9] Bonisławska I, Frołowicz T, Tomaczkowski L, Drobnik P, Pogorzelska M. Physical education lessons and primary school students' free time. Central European Journal of Sport Sciences and Medicine. 2015;10(2):79-86.

[10] Raport: Maleje aktywność fizyczna polskich nastolatków [Report: Polish teenagers' physical activity is decreasing]. Ministry of Science and Higher Education, 22.04.2019 http://naukawpolsce.pap.pl/ aktualnosci/news\%2C33688\%2Craport-maleje-aktywnosc-fizyczna-polskich-nastolatkow.html Polish.

[11] Woynarowska B, Mazur J, Oblacińska A. Uczestnictwo uczniów w lekcjach wychowania fizycznego w szkołach w Polsce [Participation of students in physical education lessons in schools in Poland]. Hygeia Public Health, 2015;50(1):183-190. Polish.

[12] Amstrong N, Welsman J. The physical activity patterns of european youth with reference to methods of assessment. Sports Medicine. 2006;12:1067-1086. https://doi.org/10.2165/00007256-20063612000005

[13] Tudor-Locke K, Lee S, Morgan C, Beighle A, Pangrazi R. Children's pedometer - determined physical activity during the segmented school day. Med Sci Sport Exerc. 2006;38:10. https://doi.org/10.1249/01. mss.0000230212.55119.98

[14] Groffik D. Struktura aktywności fizycznej młodzieży 15-17-letniej Górnego Śląska [Structure of physical activity of adolescents 15-17 years old in Upper Silesia]. Katowice: AWF; 2015. Polish.

[15] Eisenmann JC, Bartee RT, Wang MQ. Physical activity, TV viewing, and weigh in U.S. youth: Youth Risk Behavior Survey. Obes Res. 2002;10: 379-385. https://doi.org/10.1038/oby.2002.52

[16] Norman GJ, Schmid BA, Sallis JF, Calfas KJ, Patrick K. Psychosocial and environmental correlates of adolescent sedentary behaviors. Pediatris. 2005;116:908-916. https://doi.org/10.1542/peds.2004-1814

[17] Mazur J, Kleszczewska D. Aktywność fizyczna młodzieży szkolnej w wieku 10-19 lat w świetle badań HBSC (Health Behaviour in School-aged Children) [Physical activity of school adolescents aged 10-19 in the light of HBSC (Health Behavior in School-aged Children) research]. In: Fijałkowska A, editor. Aktualna ocena aktywności fizycznej dzieci i młodzieży w Polsce [Current assessment of physical activity of children and youth in Poland]. Warszawa: Institute of Mother and Child; 2018. Polish.

[18] Zembura P, Korcz A, Cieśla E, Gołdys A, Nałęcz H, Active Healthy Kids: Poland's Report Card 2018 - on Physical Activity for Children and Youth, https://www.activehealthykids.org/poland/ https://doi. org/10.1123/jpah.2018-0540

[19] The Lancet Child \& Adolescent Health: Majority of adolescents worldwide are not sufficiently physically active, putting their current and future health at risk. News Release. 21-Nov-2019 https:// www.eurekalert.org/pub_releases/2019-11/tl-pss111919.php

[20] WHO. More active people for a healthier world. The global action plan on physical activity 2018 2030. https://www.who.int/ncds/prevention/physical-activity/gappa

[21] Guthold R, Stevens AG, Riley LM, Bull FC. Global trends in insufficient physical activity among adolescents, The Lancet Child \& Adolescent Health. 2019;1:23-35. https://doi.org/10.1016/S23524642(19)30323-2 